\title{
ORNL/TM-1999/287
}

Revision 0

\section{System Requirement Document for the Molten Salt Reactor Experiment ${ }^{233} \mathrm{U}$ Conversion System}

R. D. Aigner 
This report has been reproduced from the best available copy.

Reports are available to the public from the following source. National Technical Information Service

5285 Port Royal Road

Springtield, VA 22161

Telephone 703-605-6000 (1-800-553-6847)

TDD 703-487-4639

Fax 703-605-6900

E-mail orders@ ntis.fedworld.gov

Web site http://www.ntis.gov/ordering.htm

Reports are available to U.S. Department of Energy (DOE) employees, DOE contractors, Energy Technology Data Exchange (ETDE) representatives, and International Nuclear Information

System (INIS) representatives from the following source.

Office of Scientific and Technical Information

P.O. Box 62

Oak Ridge, TN 37831

Telephone 865-576-8401

Fax 865-576-5728

E-mail reports@adonis.osti.gov

Web site http://www.osti.gov/products/sources.html

Reports produced after January 1,1996 , are generally available via the DOE Information Bridge. Web site http://www.doe.gov/bridge

This report was prepared as an account of work sponsored by an agency of the United States government. Neither the United States government nor any agency thereof, nor any of their employees, makes any warranty, express or implied, or assumes any legal liability or responsibility for the accuracy, completeness, or usefulness of any information, apparatus, product, or process disclosed, or represents that its use would not infringe privately owned rights. Reference herein to any specific commercial product, process, or service by trade name, trademark, manufacturer, or otherwise, does not necessarily constitute or imply its endorsement, recommendation, or favoring by the United States government or any agency thereof. The views and opinions of authors expressed herein do not necessarily state or reflect those of the United States government or any agency thereof. 


\section{SYSTEM REQUIREMENTS DOCUMENT}

FOR THE MOLTEN SALT REACTOR EXPERIMENT

\section{${ }^{233}$ U CONVERSION SYSTEM}

January 10, 2000

Prepared by:
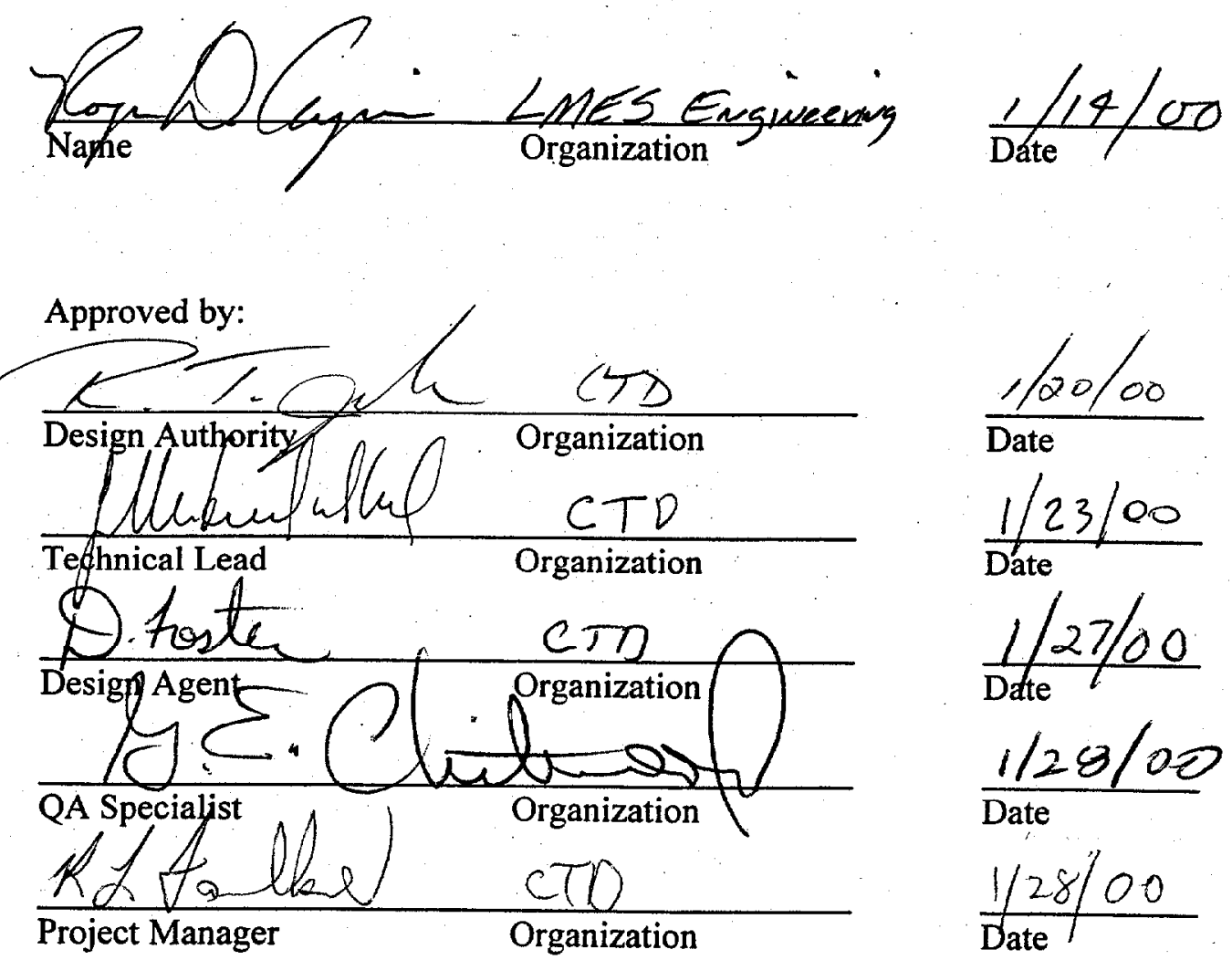

Revision Leve1/Date:

Original Issue/January 10,2000
Description:

Initial release. 


\section{CONTENTS}

ACRONYMS, ABBREVIATIONS, AND INITIALISMS $\ldots \ldots \ldots \ldots \ldots \ldots \ldots \ldots \ldots \ldots \ldots$ vii

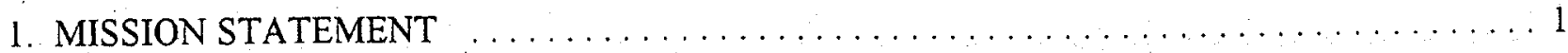

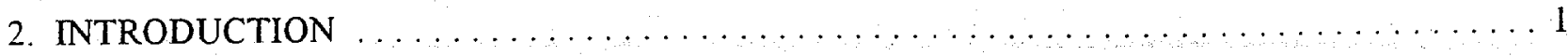

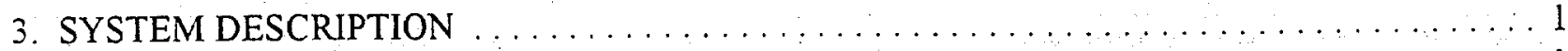

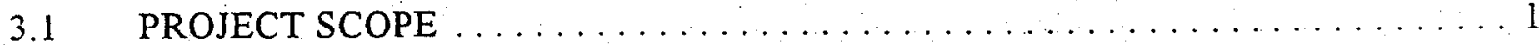

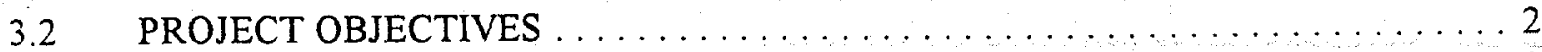

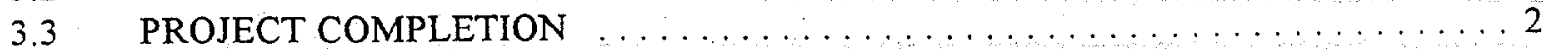

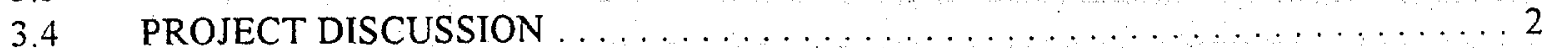

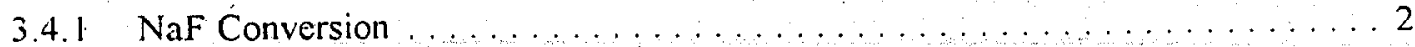

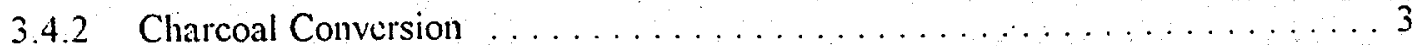

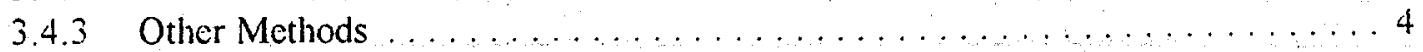

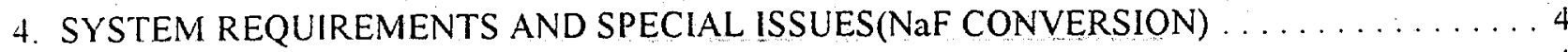

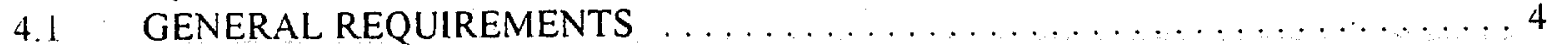

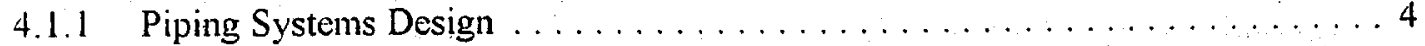

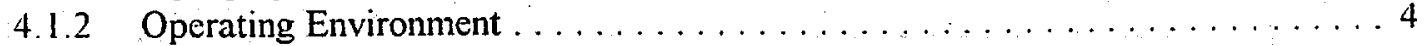

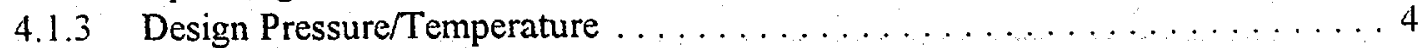

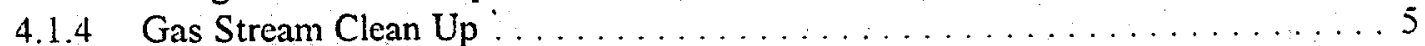

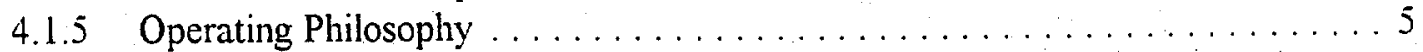

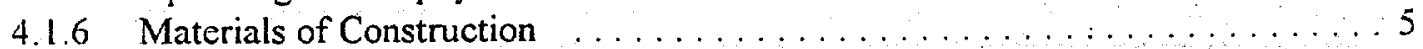

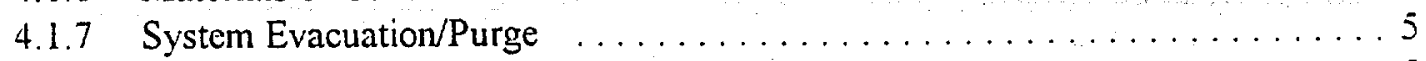

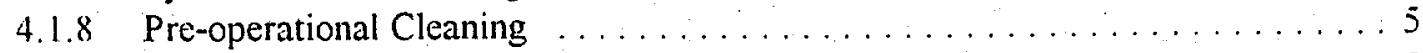

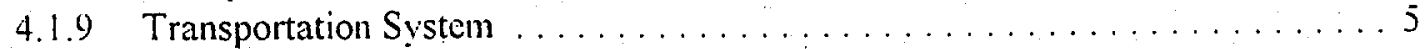

4.1.10 System/Component Designations $\ldots \ldots \ldots \ldots \ldots \ldots \ldots \ldots \ldots \ldots \ldots$

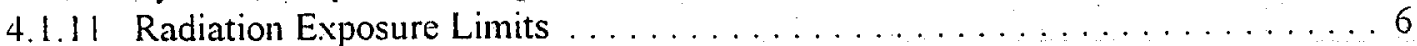

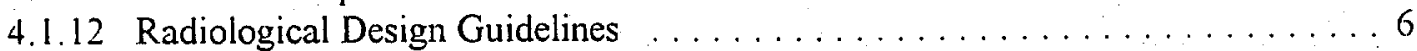

4.1 .13 Nuclear Criticality Safety . . . . . . . . . . . . . . . . . . 6

4.1 .14 Natural Phenomena Mitigation Considerations $\ldots \ldots \ldots \ldots \ldots \ldots$

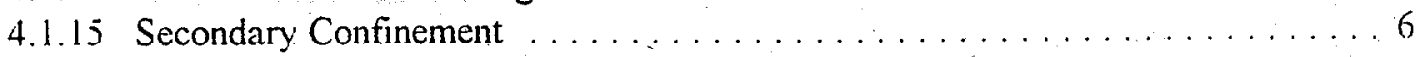

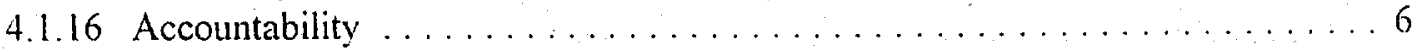

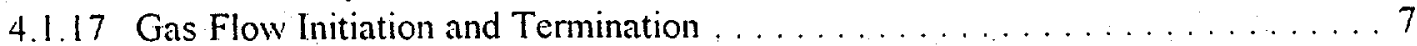

4.1 .18 Radon Decay . . . . . . . . . . . . . . . . . . . . . . . ?

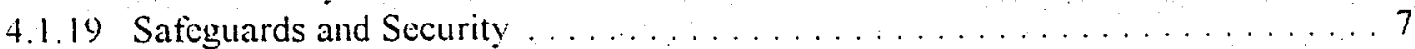

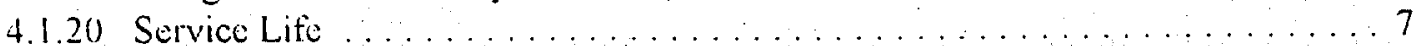

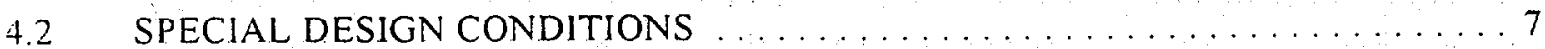

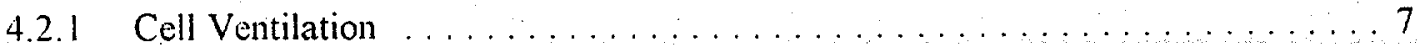

4.2 .2 Remote Operations . . . . . . . . . . . . . . . . . . . . . 7

4.2 .3 Confinement Requirements . . . . . . . . . . . . . . . . . . 7

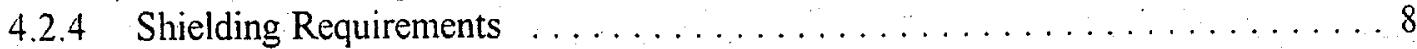

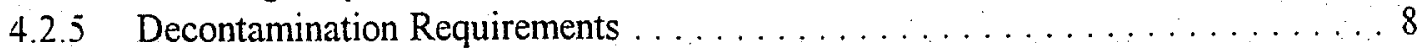


5.0 SYSTEM REQUIREMENTS FOR SPECIAL SUPPORT EQUIPMENT $\ldots \ldots \ldots \ldots \ldots \ldots \ldots$

5.1 REACTION/STORAGE VESSEL DESIGN REQUIREMENTS $\ldots \ldots \ldots \ldots \ldots .8$

5.1.1 Primary Containment $\&$ Design Life $\ldots \ldots \ldots \ldots \ldots \ldots \ldots \ldots$

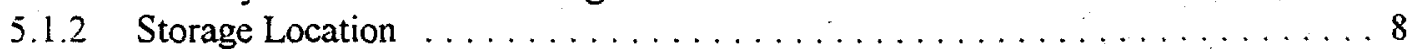

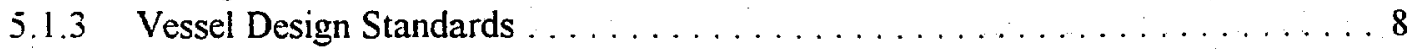

5.1 .4 Vessel Fabrication Standards $\ldots \ldots \ldots \ldots \ldots \ldots \ldots \ldots \ldots \ldots . \ldots \ldots$

5.1 .5 Normal Operating Conditions . . . . . . . . . . . . . . . . . . 9

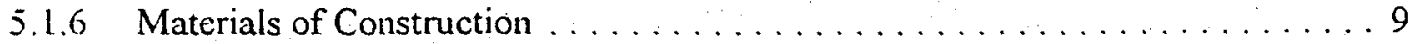

5.2 STEAM GENERATOR VESSEL DESIGN REQUIREMENTS $\ldots \ldots \ldots \ldots \ldots \ldots 9$

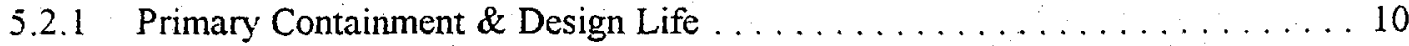

5.2 .2 Vessel Design Standards . . . . . . . . . . . . . . . . . . . . 10

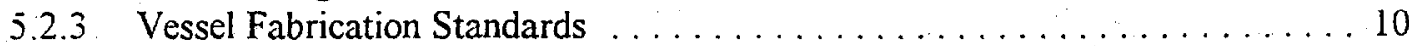

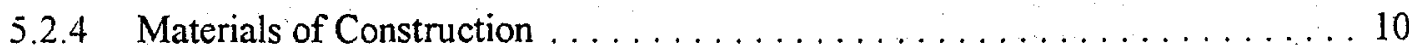

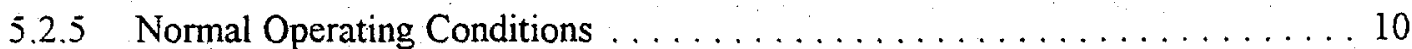

5.3 HF TRAP VESSEL DESIGN REQUIREMENTS $\ldots \ldots \ldots \ldots \ldots \ldots \ldots \ldots \ldots$

5.4 PROCESS FLUORINE TANK VESSEL DESIGN REQUIREMENTS $\ldots \ldots \ldots \ldots 11$

5.5 CONDENSER VESSEL DESIGN REQUIREMENTS $\ldots \ldots \ldots \ldots \ldots \ldots \ldots \ldots \ldots$

5.6 NAF SCRUBBER VESSEL DESIGN REQUIREMENTS $\ldots \ldots \ldots \ldots \ldots \ldots \ldots$ II

5.7 EVAPORATOR VESSEL DESIGN REQUIREMENTS $\ldots \ldots \ldots \ldots \ldots \ldots \ldots \ldots 11$

5.8 ALUMINA SCRUBBER VESSEL DESIGN REQUIREMENTS $\ldots \ldots \ldots \ldots \ldots 11$

5.9 MSRE NAF TRAP VESSEL DESIGN REQUIREMENTS $\ldots \ldots \ldots \ldots \ldots \ldots \ldots 11$

5.10 SHIELDED LOAD IN STATION DESIGN REQUIREMENTS $\ldots \ldots \ldots \ldots \ldots 12$

5.11 SHIELDED OVEN ASSEMBLY DESIGN REQUIREMENTS $\ldots \ldots \ldots \ldots \ldots \ldots 12$

5.12 THERMAL CRYOSTAT DESIGN REQUIREMENTS $\ldots \ldots \ldots \ldots \ldots \ldots \ldots \ldots 12$

5.13 FTIR ANALYTICAL CELL DESIGN REQUIREMENTS $\ldots \ldots \ldots \ldots \ldots \ldots \ldots \ldots 12$

6.0 SYSTEM REQUIREMENTS AND SPECIAL ISSUES(CHARCOAL CONVERSION) . . . . 1.2

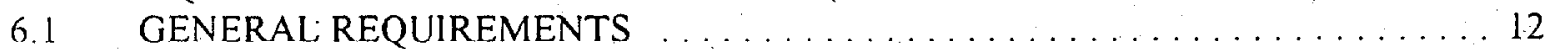




\section{ACRONYMS, ABBREVIATIONS, AND INITIALISMS}

$\begin{array}{ll}\text { ACB } & \text { Auxiliary Charcoal Bed } \\ \text { ALARA } & \text { As Low As Reasonably Achievable } \\ \text { ASME } & \text { American Society of Mechanical Engineers } \\ \text { CFR } & \text { Code of Federal Regulations } \\ \text { CPS } & \text { conversion piping system } \\ \text { DOT } & \text { Department of Transportation } \\ \text { FMCL } & \text { fissionable material control limit } \\ \text { FTIR } & \text { Fourier transform infrared } \\ \text { HEPA } & \text { high efficiency particulate air } \\ \text { hr } & \text { hour } \\ \text { mR } & \text { milli-REM } \\ \text { MSRE } & \text { Molten Salt Reactor Experiment } \\ \text { ORNL } & \text { Oak Ridge National Laboratory } \\ \text { ppm } & \text { parts per million } \\ \text { psig } & \text { pounds per square inch gauge }\end{array}$




\section{MISSION STATEMENT}

The purpose of the conversion process is to convert the ${ }^{233} \mathrm{U} /$ fluoride compounds that are being extracted from the Molten Salt Reactor Experiment (MSRE) equipment and convert the material to a stable oxide for long-term storage at Building 3019.

\section{INTRODUCTION}

The fissile material reclamation activities for the MSRE remediation project include the removal and recovery of uranium from the off-gas system, from the stored fuel salt, and finally, from the uraniumladen charcoal in the Auxiliary Charcoal Bed (ACB). Each of these operations produces an uranium/fluoride compound that is not suitable for long-term storage. The uranium-fluoride compounds can be stored for a limited period of time in pressure vessels. The interim-storage vessels are designed to handle the internal pressure buildup from gases formed by radiolysis of the uranium-fluoride compounds. The conversion process will take the pressurized vessels from interim storage and process the materials in a hot cell located at Building 4501. The gas in the vessels will be vented through chemical traps and then the traps will be processed to convert the various uranium-fluoride compounds to a stable uranium oxide form. This will be done one trap at a time.

The chemical form of uranium being extracted from the off-gas system and from fuel salt fluorination process is uranium hexafluoride $\mathrm{UF}_{6}$. During the operations at MSRE, the $\mathrm{UF}_{6}$ is chemisorbed onto sodium fluoride $(\mathrm{NaF})$ traps where it forms the complex, $2 \mathrm{NaF} \cdot \mathrm{UF}_{6}$. The conversion process that will be installed in the Building 4501 Hot Cell $\mathrm{D}$ will recover the $\mathrm{UF}_{6}$ from the $\mathrm{NaF}$ traps by decomposition of the binary complex at elevated temperatures $\left(>300^{\circ} \mathrm{C}\right)$. After the uranium is extracted from the $\mathrm{NaF}$ traps, it is collected in the conversion process reaction vessel. The reaction vessel is then hydrolized and heated through several step operations up to $900^{\circ} \mathrm{C}$ in order to convert the material to a stable uranium oxide.

The $\mathrm{ACB}$ at MSRE contains uranium-laden charcoal with unstable $\mathrm{C}_{\mathrm{x}} \mathrm{F}$ compounds. After extraction at MSRE, this material will be delivered to Building 4501 Hot Cell $\mathrm{D}$ for processing to a stable oxide. The charcoal conversion process is still under development, with mockup and full scale testing of the proposed flow sheet funded in FY 99 and FY 00 . The uranium-laden charcoal has been pre-treated with ammonia to prevent the deflagration of the $\mathrm{C}_{\mathrm{x}} \mathrm{F}$ if localized heating $\left(>\sim 150^{\circ} \mathrm{C}\right)$ occurs during the charcoal removal process. Prior to removal, the treatment will be performed a second time to denature the 1 to $5 \%$ reformation of $\mathrm{C}_{x} \mathrm{~F}$ that has occurred due to radiolysis of $\mathrm{NH}_{4} \mathrm{~F}$. The uranium-laden charcoal will be physically extracted and stored in several pressure vessels at MSRE until the conversion process is designed and installed in Hot Cell $\mathrm{A}$ in Building 4501.

\section{SYSTEM DESCRIPTION}

\subsection{PROJECT SCOPE}

Because the chemical stability of the $2 \mathrm{NaF} \cdot \mathrm{UF}_{6}$ complex and the uranium-laden charcoal are not suitable for long term storage, these materials must be converted into a more stable chemical 
form such as the oxide, $\mathrm{U}_{3} \mathrm{O}_{8}$. Because of the hazard associated with the high energy $(2.6 \mathrm{MeV})$ gamma radiation emitted from ${ }^{208} \mathrm{Tl}$, a daughter of ${ }^{232} \mathrm{U}$, the conversion process must be performed in a hot cell. Equipment shall be designed, fabricated and installed in accordance with this document. Inspection and testing of the system shall be accomplished through the use of test plans and procedures. Operation of the system will not commence until fabrication packages, engineering as-built drawing packages, test plans and procedural walk-downs have been completed and approved.

Due to space limitations in the hot cells, there will be one processing system designed and installed in Hot Cell D in Building 4501 for converting the $2 \mathrm{NaF} \cdot \mathrm{UF}_{6}$ complex to an oxide and one processing system designed and installed in Hot Cell A in Building 4501 for converting uranium-laden charcoal to an oxide. The scope of this document will be limited to only the $2 \mathrm{NaF} \cdot \mathrm{UF}_{6}$ conversion process until the development work for the charcoal material has been completed.

\subsection{PROJECT OBJECTIVES}

The main objective of the conversion process is to transform the reactive and volatile $\mathrm{UF}_{6}$ to a stable uranium oxide by replacing fluorine with oxygen. The main criteria used for the process selection are the following:

- Minimize uranium losses

- Minimize secondary wastes and contamination

- Simplicity and adaptability to small scale hot-cell operation

- No stirring, mixing, or transfers between vessels

- $\quad$ No need for purity (except as required for long-term storage)

- Suitable to treat all of the materials $\left(2 \mathrm{NaF} \cdot \mathrm{UF}_{6}\right.$ complex, uranium-laden charcoal, fluoride salt, and miscellaneous ${ }^{233} \mathrm{U}$-containing materials)

\subsection{PROJECT COMPLETION}

The project shall be deemed complete when (1) all of the $2 \mathrm{NaF} \cdot \mathrm{UF}_{6}$ complex materials and the uranium-laden charcoal received from the MSRE has been processed into stable oxide forms and transported to Bldg. 3019 for storage; (2) waste generated as a result of the process of conversion has been identified and appropriately disposed of; (3) the process equipment has been removed from the cells and disposed of; and (4) the cells have been cleaned to their initial condition.

\subsection{PROJECT DISCUSSION}

The process consist of two uranium reclamation schemes interconnected with the oxide conversion unit. Most of the equipment is common to three steps.

\subsubsection{NaF Conversion}

The first part of the process relates to the recovery of the uranium contained in the NaF traps and is shown in Fig. 1. As mentioned, the $\mathrm{UF}_{6}$ from the off-gas system is being chemisorbed onto sodium fluoride $(\mathrm{NaF})$ traps where the $\mathrm{UF}_{6}$ forms a complex $\left(2 \mathrm{NaF} \cdot \mathrm{UF}_{6}\right)$ which decomposes at 
higher temperatures $\left(>300^{\circ} \mathrm{C}\right) . \mathrm{UF}_{6}$ is desorbed from the heated $\mathrm{NaF}$ trap $\left(300-450^{\circ} \mathrm{C}\right)$ in a closed-loop (below hot-cell pressure) and condensed in a cooled vessel. A small volume of fluorine gas is continuously circulated at a pressure below the external hot-cell pressure using a double-sealed metal bellows pump.

The purpose of the fluorine is two fold: first as a gas carrier and second as a fluorination agent to recover any oxyfluorides or lower fluorides that could be present in the trap. Two in-line infrared (IR) gas cells located before and after the $\mathrm{UF}_{6}$ conversion vessel are used to monitor the completeness of the recovery. Any $\mathrm{UF}_{6}$ that could escape condensation in the cooled conversion vessel will be re-circulated and trapped afterward. Most of the fluorine, except the volume of the piping loop, will be recycled and reused. All lines will be evacuated and filled-up with an inert gas helium $(\mathrm{He})$ prior to trap removal. A soda-lime trap is located before the vacuum pump to ensure that not even traces of fluorine or uranium could leave the system. Alternatively, the $\mathrm{UF}_{6}$ can be recovered by (a) diffusion from the heated $\mathrm{NaF}$ trap into the cooled conversion vessel in a static mode or (b) a combination of static diffusion followed by fluorine circulation.

The conversion of the frozen $\mathrm{UF}_{6}$ into $\mathrm{U}_{3} \mathrm{O}_{8}$ will be conducted in the same conversion vessel used in the previous steps as shown in Fig. 3. Initially, a slight excess of water vapor will be condensed as ice on top of the frozen $U_{6}$. The vessel will be allowed to warm-up resulting in the formation of solid $\mathrm{UO}_{2} \mathrm{~F}_{2} \bullet \mathrm{H}_{2} \mathrm{O}$ and $\mathrm{HF}$. A freezing-thawing cycle is repeated two or three times to ensure complete hydrolysis of the $\mathrm{UF}_{6}$ and to promote cracking of the solid cake that will facilitate the further steam treatment. The resulting solid cake will be step-heated and sequentially contacted with pressurized steam. The steam will penetrate into the cake, gradually reacting with the oxyfluoride-oxide mixture forming HF. The HF and steam will be transported to an HF trap in each step until completion. Wet air will be injected at the end of the process when the system reaches a temperature of $600-650^{\circ} \mathrm{C}$ to complete the reaction. The vessel will then be heated up to about $850^{\circ} \mathrm{C}$ under wet air to produce $\mathrm{U}_{3} \mathrm{O}_{8}$. At the end, the vessel will be allowed to cool-down. The lines will be evacuated and filled with an inert gas. The vessel will then be disconnected, capped, placed in an overpack, and removed from the cell to be transported to Bldg. 3019 for storage. Alternatively, the oxide product can be removed, characterized and transferred to a final storage container before transportation to the Bldg. 3019 storage wells.

\subsubsection{Charcoal Conversion}

The second sub-unit, shown in Fig. 2, is for the recovery and condensation of $\mathrm{UF}_{6}$ from the passivated activated charcoal. The charcoal trap will be connected to the Fourier transform infrared (FTIR) gas cells and the conversion vessel. An intermediate trap (an empty vessel with a liquid-nitrogen cooled cold finger in the center) will be present during the initial heating of the charcoal to condense the ammonium fluoride $\left(\mathrm{NH}_{4} \mathrm{~F}\right)$. Once the charcoal reaches approximately 600 , it will be burned to carbon tetrafluoride $\left(\mathrm{CF}_{4}\right)$ using $\mathrm{F}_{2}$. Above $500^{\circ} \mathrm{C}$ charcoal burns completely with $\mathrm{F}_{2}$ producing gaseous $\mathrm{CF}_{4}$ and a small fraction of $\mathrm{C}_{2} \mathrm{~F}_{6}$ and higher fluorocarbons. No intermediate fluorinated charcoal is formed at these high temperatures. The uranium is retained by the charcoal until almost all of the charcoal is transformed into gaseous fluorocarbons. When the charcoal is converted to $\mathrm{CF}_{4}$, the uranium is fully fluorinated to the volatile $\mathrm{UF}_{6}$. The recovered $\mathrm{UF}_{6}$ will be condensed in the conversion vessel. The heavier fluorocarbons that are formed as minor byproducts and that will also condense, do not interfere with the further processing of the $\mathrm{UF}_{6}$ into uranium oxide.

The $\mathrm{F}_{2}$ flow will be stopped once the $\mathrm{CF}_{4}$ is no longer detected by the FTIR gas cells, indicating that all the charcoal has been removed as $\mathrm{CF}_{4}$. As before, the soda-lime trap located in front of 
the vacuum pump will trap any fugitive fluorine or uranium. The $\mathrm{CF}_{4}$ will leave the system through a long coil of tubing to allow for the safe decay of the radioactive uranium daughters. Alternatively, the $\mathrm{F}_{2}$ burning will be performed in a closed-loop mode starting from an evacuated system and continuing until system pressure is slightly below atmospheric pressure. At this point, the $\mathrm{CF}_{4}$ will be released prior to starting another close-loop burning cycle.

\subsubsection{Other Methods}

Another method presently under testing consists of burning the charcoal with oxygen at a lower temperature $\left(-400^{\circ} \mathrm{C}\right)$ in a closed system. The $\mathrm{CO}_{2}$ formed will be collected as a frozen solid. The charcoal burning will be followed by a waiting period to allow for the decay of radon daughters before releasing the $\mathrm{CO}_{2}$. As envisioned, uranium will remain in the original charcoal container as uranium fluoride or oxyfluoride. These fluorides or oxyfluorides will then be converted to $\mathrm{UF}_{6}$ using the $\mathrm{F}_{2}$ closed-loop treatment shown in Fig. 1.

\section{SYSTEM REQUIREMENTS AND SPECIAL ISSUES(NAF CONVERSION)}

\subsection{GENERAL REQUIREMENTS}

\subsubsection{Piping Systems Design}

The Conversion Process System (CPS) primary piping shall be designed and fabricated in accordance with ANSI Standard B31.3 for all process piping and components with the exception of vessel design.

\subsubsection{Operating Environment}

The CPS primary piping shall be compatible with a gas stream containing the following:
a) UF6@0-400 mm Hg
b) $\mathrm{F}_{2} @ 0-1000 \mathrm{~mm} \mathrm{Hg}$
c) $\mathrm{MoF}_{6} @ 0-50 \mathrm{~mm} \mathrm{Hg}$
d) $\mathrm{CF}_{4} @ 0-400 \mathrm{~mm} \mathrm{Hg}$
e) $\mathrm{HF}$

1)@0-1000 mm Hg during circulation

2)@.:50\% concentration from Thermal Cryostat to HF Condenser

f) $\mathrm{NF}_{3}$ (trace)

g) $\mathrm{N}_{2} \mathrm{~F}_{4}$ (trace)

h) $\mathrm{ClF}_{3} @ 0-200 \mathrm{~mm} \mathrm{Hg}$

i) $\mathrm{PuF}_{6}$ (trace)

Helium is expected to make up the balance of the gas stream.

\subsubsection{Design Pressure/Temperature}

The CPS primary piping shall be designed to maintain confinement between 300 psig maximum

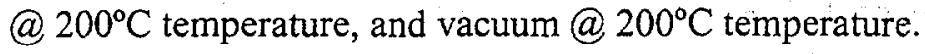




\subsubsection{Gas Stream Clean Up}

The CPS shall be capable of removing the following constituents from the CPS piping gas stream prior to disconnecting conversion vessels/traps:
a) $\mathrm{UF}_{6}$
b) $\mathrm{F}_{2}$
c) $\mathrm{ClF}_{3}$
d) $\mathrm{HF}$
e) $\mathrm{PuF}_{6}$

\subsubsection{Operating Philosophy}

The CPS shall be designed for intermittent operating cycles as a batch process. The remainder of the time, the system will be in a standby condition.

\subsubsection{Materials of Construction}

All piping components, including vessels, expected to be in direct contact with the gas stream during normal operations shall be fabricated from Monel Alloy 400 and/or of proven service within operating environments similar to that defined in 4.1.2. The line from the Thermal Cryostat to the HF Condensor shall be fabricated from Haynes 230 Alloy.

\subsubsection{System Evacuation/Purge}

The CPS shall be configured such that piping components can be evacuated and purged by inert gas as necessary.

\subsubsection{Pre-operational Cleaning}

All piping components, including vessels, expected to be in direct contact with the process gas stream during normal operation shall be thoroughly cleaned and conditioned following fabrication but prior to system operation. Cleaning shall be in accordance with procedures contained in ANSI N14.1-1990, American National Standard for Nuclear Materials - Uranium Hexafluoride - Packaging for Transport.

\subsubsection{Transportation System}

The transportation system (cask, overpack, and procedures) shall comply with the guidelines contained in ORNL/M-808, Lockheed Martin Energy Research, Inc., Oak Ridge National Laboratory "On-Site Transportation Operations Manual for Transporting Hazardous Materials and Hazardous Wastes", and ORNL Radiological Protection Procedure RPP-420, "Release and Transport of Radioactive Materials". The transportation system shall be described in a Transportation Plan, which shall be reviewed and approved by the ORNL Transportation Safety \& Compliance Manager and the Transportation Operations Site Manager prior to intra-plant transport of a processed conversion vessel.

\subsubsection{System/Component Designations}

All system and component designators (valve numbers, line numbers, equipment identifications) on engineering drawings and specifications shall be consistent with the existing Building 4501 Cell D labeling system. 


\subsubsection{Radiation Exposure Limits}

The CPS (equipment and procedures) design shall be such that the radiation exposure limits comply with the ORNL Office of Radiation Protection Procedures RPP-128, "Radiological Design Considerations", RPP-210, "Administrative Control Levels and Dose Limits", and RPP310, "Planning Radiological Work". Additionally, ALARA principles shall be incorporated into system design.

\subsubsection{Radiological Design Guidelines}

ORNL Office of Radiation Protection Procedure RPP-128, "Radiological Design Considerations" and its Appendix A shall be used in determining the adequacy of the CPS design features for radiological considerations.

\subsubsection{Nuclear Criticality Safety}

System (equipment and procedures) design shall be such that compliance with the requirements of ORNL-NS-PO2, "Nuclear Criticality Safety Program" is maintained.

\subsubsection{Natural Phenomena Mitigation Considerations}

a) Analysis shall be performed to evaluate the integrity of the structure of the building 4501 facility that houses Hot Cell D, where the CPS is to be installed and shall meet the requirements of DOE-STD-1021-93'.

b) Modifications and/or additions to the Building 4501 facility Hot Cell D structures, systems and components, shall be designed and analyzed for Natural Phenomena Hazards Mitigation to meet the requirements of DOE Order 420.1, "Facility Safety".

\subsubsection{Secondary Confinement}

Vessels and components which may be expected to convey and/or accumulate more than trace quantities of uranium upstream of the final trap vessel during operation of the CPS shall be secondarily confined in a hot cell. The CPS will be installed inside a hot cell to protect workers from gaseous release, radiation and contamination associated trap constituents. The hot-cell pressure will be maintained negative relative to the pressure in the adjacent operating area.

\subsubsection{Accountability}

Operations within the Building 4501 facility shall meet the minimum requirements and procedures for the control and accountability of nuclear materials as prescribed in DOE Order 5633-3B," Control and Accountability of Nuclear Materials". 


\subsubsection{Gas Flow Initiation and Termination}

Venting of the CPS off-gas piping shall be controlled. Termination of the venting operation shall be performed by operation of redundant solenoid-operated valves.

\subsubsection{Radon Decay}

The system shall be configured such that a minimum hold-up time of not less than 10 minutes is provided for the "cleaned" effluent gas in order for adequate radon decay to occur.

\subsubsection{Safeguards and Security}

There shall be no more than $2 \mathrm{~kg}$ of uranium accessible within hot cells A \&D at any time.

\subsubsection{Service Life}

CPS components shall be designed for a service life of not less than 10 years except for portions of the system that are specifically identified for replacement due to high concentrations of corrosive gas.

\subsection{SPECIAL DESIGN CONDITIONS}

\subsubsection{Cell Ventilation}

Ventilation of the cell will draw air from the operating area through the cell and then send it on to the 3039 stack.

\subsubsection{Remote Operations}

Operations in the hot cell will require the use of manipulators or remote-control of processes (e.g., remotely air operated valves). Process design and layout shall accommodate remote operations and shall minimize cell entry for hands-on operation.

\subsubsection{Confinement Requirements}

Both the environment and operational areas must be protected from the ${ }^{233} \mathrm{U}$. Confinement shall be governed by the following requirements:

a) The process equipment (i.e., the piping, valves, and vessels) shall serve as the primary confinement.

b) Additionally, all processing of $\mathrm{UF}_{6}$ shall be performed sub-atmospheric.

c) The hot cell provides secondary confinement The hot cell pressure is maintained negative with respect to the adjacent operating areas to ensure that air flow is into the cell.

d) Normal air intake into the cell shall be HEPA filtered. Air exhaust from the cell and from the hot cell off gas system shall be HEPA filtered prior to release through the 3039 stack. 
e) Process instrumentation (e.g., pressure transducers) shall be available to provide indications of a breech of primary confinement. Process piping shall be segmented by closure of valves to isolate such a breech.

\subsubsection{Shielding Requirements}

Shielding for protection of operating personnel is provided by the hot-cell walls, viewing windows, and cell access doors. Localized shielding of sources shall be provided to protect equipment, eliminate potential streaming pathways, and allow for operator entry, if necessary. Shielding shall be designed and implemented following guidelines defined by 4.1.11 and 4.1.12 of this document. Shielding for operations shall include the following:

a) During transportation operations, shielding shall be provided by a shielded carrier.

b) Inside the cell, the trap load-in station and the desorption station shall be shielded. See Section 5.10 and 5.11 of this document.

\subsubsection{Decontamination Requirements}

The equipment/system shall be designed to facilitate decontamination to the maximum extent practicable.

\subsection{SYSTEM REQUIREMENTS FOR SPECIAL SUPPORT EQUIPMENT}

\subsection{REACTION/STORAGE VESSEL DESIGN REQUIREMENTS}

\subsubsection{Primary Containment \& Design Life}

The conversion/storage vessel shall provide the primary containment for ${ }^{233} \mathrm{U}$ and/or $\mathrm{HF}$ and/or $\mathrm{F}_{2}$ contained in oxide form for a storage life of not less than 50 years. Trap vessel penetrations shall be sealed with threaded end caps or similar fittings when not connected to the CPS process piping.

\subsubsection{Storage Location}

The conversion/storage vessel and overpack shall be designed for storage within existing storage wells in Building 3019. Size limitations shall be less than 4 inches in diameter, and 21.25 inches tall.

\subsubsection{Vessel Design Standards}

The conversion vessel shall be designed in accordance with ASME Boiler and Pressure Vessel Code Section VIII, Division I. 


\subsubsection{Vessel Fabrication Standards}

To ensure fabrication in accordance with NQA-1, the trap vessel shall be fabricated in accordance with the ORNL Quality Assurance Procedures as outlined in the ORNL Standard Practice Procedures.

\subsubsection{Normal Operating Conditions}

The vessel shall be designed to meet the following conditions:

a) One (1) atmosphere (15 psig) external pressure at a maximum temperature of approximately 450 degrees $C$ ( 842 degrees $F$ ) for a continuous operating period not to exceed 24 hours. Calculations for this operating condition shall be made using best engineering practices and methods. This calculation reflects the requirement of the vessel to safely withstand normal operating conditions when $\mathrm{UF}_{6}$ is being frozen inside the vessel using liquid nitrogen and the vessel is at internal sub-atmospheric pressure. Gas flows will be controlled during this operation.

b) 300 psig internal working pressure at a maximum temperature of 650 degrees $C(1202$ degrees F) for a continuous operating period not to exceed 8 hours. Calculations for this operating condition shall be made using the ASME Boiler \& Pressure Vessel Code (B\&PVC) Section VIII, Division I. This calculation reflects the requirement of the vessel to safely withstand normal operating conditions when injecting steam into the vessel.

c) 200 psig internal working pressure at a maximum temperature of 885 degrees C (1625 degrees $F$ ) for a continuous operating period not to exceed 8 hours. Calculations for this operating condition shall be made using the ASME Boiler \& Pressure Vessel Code (B\&PVC) Section VIII, Division I. This calculation reflects the requirement of the vessel to safely withstand normal operating conditions while subjecting the vessel to final heating operations using wet air.

d) One (1) atmosphere (15 psig) external pressure at a maximum temperature of 250 degrees $\mathrm{C}$ (482 degrees F) for a continuous period not to exceed 1 hour. Calculations for this operating condition shall be made using the ASME Boiler and Pressure Vessel Code (B\&PVC) Section VIII Division I. This calculation shall meet the requirements for transportation as specified in DOE Order 440.1.

\subsubsection{Materials of Construction}

Fabrication of the conversion vessel shall be done using Haynes $230 \mathrm{Ni}$ alloy. Fittings external to the primary confinement envelope may be 300 series stainless steel.

\subsection{STEAM GENERATOR VESSEL DESIGN REQUIREMENTS}

Preliminary concept of steam generator provides for an external Watlow electric heating furnace. The amount and rate of steam generated will depend upon the operational phase where the steam will be used. (controller criteria? an on-off controller with too much power could overheat the $U_{6}$ ) During the initial "icing" phase, a predetermined amount of water will be slowly heated to boiling at sub-atmospheric pressure. This saturated steam provides water vapor which will be used to cover the desorbed $\mathrm{UF}_{6}$ with water ice. Later, up to a dozen steam pressurization and 
release cycles at 200 psig nominally, will be used to hydrate and defluorinate the $\mathrm{UO}_{2} \mathrm{~F}_{2}$ at temperatures up to $600^{\circ} \mathrm{C}$.

Placement of the steam generator in the hot cell should allow 2nd closest proximity to the reaction vessel, at an elevation to promote drainage of condensate ${ }^{<?>}$ to the reaction vessel, but toward the rear or side of the cell to allow visual and tactile access to other components.

Instrumentation in the preliminary concept consists only of an electrically sensed Bourdon pressure transducer, but level indication may be desirable. A precise water metering device inside the cell and after the back flow preventers might be necessary for controlling the amount of water needed for the initial hydration reaction.

\subsubsection{Primary Containment \& Design Life}

The steam generator vessel shall provide the primary containment for ${ }^{233} \mathrm{UF}_{6}$ and/or $\mathrm{HF}$ and/or $\mathrm{F}_{2}$ for a service life of not less than 10 years. Trap vessel penetrations shall be sealed with VCR type or similar fittings when not connected to the CPS process piping.

\subsubsection{Vessel Design Standards}

The steam generator vessel shall be designed in accordance with ASME Boiler and Pressure Vessel Code Section VIII, Division I.

\subsubsection{Vessel Fabrication Standards}

To ensure fabrication in accordance with NQA-1, the steam generator vessel shall be fabricated in accordance with the ORNL Quality Assurance Procedures as outlined in the ORNL Standard Practice Procedures.

\subsubsection{Materials of Construction}

Fabrication of the steam generator shall be done using any commercially available 400 series stainless steel.

\subsubsection{Normal Operating Conditions}

The vessel shall be designed to meet the following conditions:

Design Pressure:

Operating Pressure:

Design Temperature:

Operating Temperature:

Diameter:

Volume:

Ports:
$300 \mathrm{psig}$

200 psig

$417+$ controller margin ${ }^{\circ} \mathrm{F}$

$381+$ controller margin ${ }^{\circ} \mathrm{F}$

4" max.

1 liter liquid, 2 liters vapor space

1 pressure tap, 1 liquid inlet, 1 steam outlet, 1 relief valve outlet 
(Ports may be combined, if required.)

a) 300 psig maximum internal working pressure at a maximum temperature of 232 degrees $C$ ( 450 degrees $F$ ) for a continuous operating period not to exceed 8 hours. Calculations for this operating condition shall be made in accordance with the ASME Boiler and Pressure Vessel Code (B\&PVC) Section VIII Division I.

b) 15 psig internal working pressure at a maximum temperature of 885 degrees $C$ ( 1625 degrees $F$ ) for a continuous operating period not to exceed 8 hours. Calculations for this operating condition shall be made using standard engineering calculations based on ANSI B31.3 requirements. This calculation reflects the requirement of the vessel to safely withstand normal operating conditions when not injecting wet oxygen into the vessel and the vessel is at sub-atmospheric pressure.

c) One (1) atmosphere (15 psig) external pressure at a maximum temperature of 250 degrees $C$ ( 482 degrees $F$ ) for a continuous period not to exceed 8 hours. Calculations for this operating condition shall be made using the ASME Boiler and Pressure Vessel Code (B\&PVC) Section VIII Division I.

\subsection{HF TRAP VESSEL DESIGN REQUIREMENTS}

(TBD in later revision)

\subsection{PROCESS FLUORINE TANK VESSEL DESIGN REQUIREMENTS}

(TBD in later revision)

\subsection{CONDENSER VESSEL DESIGN REQUIREMENTS}

(TBD in later revision)

\subsection{NAF SCRUBBER VESSEL DESIGN REQUIREMENTS}

(TBD in later revision)

\subsection{EVAPORATOR VESSEL DESIGN REQUIREMENTS}

(TBD in later revision)

\subsection{ALUMINA SCRUBBER VESSEL DESIGN REQUIREMENTS}

(TBD in later revision)

\subsection{MSRE NAF TRAP VESSEL DESIGN REQUIREMENTS}

$$
\text { (TBD in later revision) }
$$




\subsection{SHIELDED LOAD IN STATION DESIGN REQUIREMENTS}

(TBD in later revision)

5.11 SHIELDED OVEN ASSEMBLY DESIGN REQUIREMENTS

(TBD in later revision)

\subsection{THERMAL CRYOSTAT DESIGN REQUIREMENTS}

(TBD in later revision)

\subsection{FTIR ANALYTICAL CELL DESIGN REQUIREMENTS}

(TBD in later revision)

6.0 SYSTEM REQUIREMENTS AND SPECIAL ISSUES(CHARCOAL CONVERSION)

(TBD in later revision)

\subsection{GENERAL REQUIREMENTS}

(TBD in later revision) 
ORNL/TM-1999/287

Revision 0

\section{INTERNAL DISTRIBUTION}

1. Aigner, R.D.

2. Chitwood, G.E.

3. Collins, J.L.

4. Cosgrove, J.M.

5. Creech, L. E.

6. Cronan, M.D.

7. Del Cul, G. D.

8. Faulkner, R.L.

9. Foster, D. J.

10. Gilpin, L.L.

11. Haghighi, M.H.

12. Hodges, E.M.

13. Icenhour, A.S.
14. Knox, P.G.

15. Lee, D.L.

16. Luk, K.H.

17. Owen, B.A.

18. Phillips, L.D.

19. Platfoot, J.H.

20. Reed, D.A.

21. Shoun, R.R.

22. Simmons, D.W.

23. Slaten, J.R.

24. Travis, J.R.

25. Westbrook, J.L.

26. ORNL Laboratory Records-RC 
